\title{
㐘周病が誘因と考えられた巨大なエプーリスおよび上顎洞炎の併発例
}

\author{
斉藤博之・金村成智・上松伸雄・東條博充 \\ 森本伊知郎・武田元一・堀 亘孝
}

\section{A case of large epulis and maxillary sinusitis by marginal periodontitis}

\author{
Hiroyuki SaItoh - Narisato Kanamura - Nobuo Uematsu \\ Hiromitsu Тојон - Ichiroh Morimoto • Genichi TAKeda \\ Nobutaka Hori
}

\begin{abstract}
A 51-year-old female noted the tumor, arising from the 167 region of alveolar ridge around November 1982.

The tumor gradually increased in size, and the patient was referred to our department in November 1983. Two epulises bad elastic hard, smooth, surfaces.

In the orall cavity, two large tumors, pyorrhoer alveolaire, dental calculus were found.

Radiographic examination revealed a horizontally absorption over the alveolus dentalis. Tomographic examination revealed lower radiolucency in the left maxillary sinus than in the right.

Under local anethsethia, these epulises were extirpated and extracted $\frac{3 \mid 2-8}{8543 \mid 8}$.

Pathologically, the surface of the epulis is covered by squamous epithelium with frequent and irregular elongation of rete ridges. Subepithelial tissue is loosely or densely fibrous and rich in vasculatures.
\end{abstract}

Postoperative, inflammation in the maxillary sinus disappeared.

Key words: epulis, maxillary sinusitis

\section{緒言}

エプーリスとは，歯肉部に生じた良性の限局性腫瘤を 総括した臨床名として用いられている11.

今回，上顎左側且歯部に巨大なエプーリスが認めら れ，同側の崡性上頸洞炎を伴った症例を経験したので， 報告する.

\section{症例}

患 者: 51 歳 女性.

京都府立医科大学附属病院菌科

(主任：堀 亘孝助教授)

Department of Dentistry, Kyoto prefectual University of Medicine (Chief: Subproffessor. Nobutaka Hori)

受付日：昭和61年 3 月 24 日
初診：昭和58年11月

主 訴： $\mid 67$ 部の腫瘤.

家族歴：特記事項なし。

既往歴：特記事項なし.

現病歴: 初診 1 年前に 167 部の腫瘤に気づいたが, 自 発痛はなく、そのまま放置していた，腫瘤は徐々に增大 し, 咀啷障害が生じたため, 当科への受診にいたった。

現 症

全身所見：体格,栄養ともにやや不良であるが,その他 異常は認められなかった。

局所所見：顔貌には，異常は認められなかった。

口腔内所見 167 部口蓋側に有茥性,クルミ大で, 表 面滑沢で多面体の腫瘤が存在し，さらに，その後方 $\mid \underline{8}$ 部口蓋側に小指頭大の腫瘤が認められ(写真1), 看瘤 のため閉口障害があった。歯は $\frac{8-2}{8543 \mid} \mid \frac{3-8}{8}$ が現存し， すべてに動畄がみられ，多量の歯石沈着が認められた。

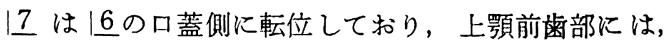

2) | 3 支台歯の 2 歯ダミーのブリッジが装着されてい 
表 1 臨床㛟查結果

\begin{tabular}{|c|c|c|c|}
\hline \multicolumn{4}{|l|}{ 臨床検査成縜 } \\
\hline WBC & $7.2 \times 10^{3}$ 個 $/ \mathrm{mm}^{3}$ & LDH & $266 \mathrm{wU}$ \\
\hline $\mathrm{RBC}$ & $4.07 \times 10^{6}$ 個 $/ \mathrm{mm}^{3}$ & GOT & $13 \mathrm{KU}$ \\
\hline $\mathrm{Hb}$ & $11.8 \mathrm{~g} / \mathrm{d} l$ & GPT & $4 \mathrm{KU}$ \\
\hline $\mathrm{Ht}$ & $35.0 \%$ & $\mathrm{ALP}$ & $8.0 \mathrm{KU}$ \\
\hline HEMOGAM & $(\%)$ & $\mathrm{T}-\mathrm{BiL}$ & $0.4 \mathrm{mg} / \mathrm{d} l$ \\
\hline N. Meta & 0 & 総コレステロール & $193 \mathrm{mg} / \mathrm{d} l$ \\
\hline N. Band & 5 & 総タンパク & $7.8 \mathrm{~g} / \mathrm{d} l$ \\
\hline N. Seg & 59 & 蛋白分画 & \\
\hline Eo & 2 & ALB & $49.6 \%$ \\
\hline $\mathrm{Ba}$ & 1 & $\alpha_{1}-\mathrm{G}$ & $3.2 \%$ \\
\hline Ly & 20 & $\alpha_{2}-\mathrm{G}$ & $11.6 \%$ \\
\hline Mo & 12 & $\beta-G$ & $11.3 \%$ \\
\hline Aty & 1 & $y-G$ & $24.3 \%$ \\
\hline P.T. & 10.1秒 & $\mathrm{A} / \mathrm{G}$ & $1.0 \%$ \\
\hline A.P.T.T. & 27.6 秒 & ナトリウム & $142 \mathrm{mEq} / l$ \\
\hline VDRL & 陰性 & カリウム & $4.2 \mathrm{mEq} / l$ \\
\hline TPHA & 陰性 & 尿菜窒素 & $13 \mathrm{mg} / \mathrm{d} l$ \\
\hline HBs 抗原 & 陰性 & クレアチン & $0.9 \mathrm{mg} / \mathrm{d} l$ \\
\hline CRP & $1+$ & 血糖 & $112 \mathrm{mg} / \mathrm{d} l$ \\
\hline ASLO & 16 単位 & 血清鉄 & $75 \mu \mathrm{g} / \mathrm{d} l$ \\
\hline
\end{tabular}

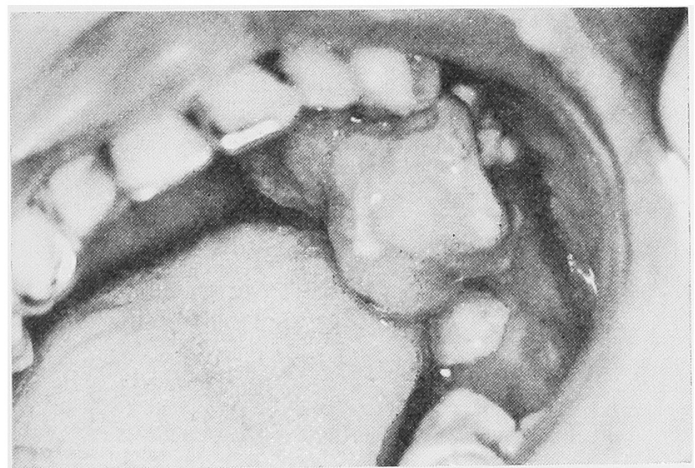

写真 1 初䛦時の口腔内写真

た。をた，歯髄崄断の結果，白は有髄崡であった。

X線所見：オルソパントモグラム（写真 2) により， 上下顠歯槽部の著明な水平吸収が認められた，前額断断 層写真 (写真 3) では, 左側上顎洞粘膜の肥厚が認めら れ，さらに，上顎洞底の骨の吸収が認められた。

臨床検査所見：軽度の炎症所見および $\mathrm{A} / \mathrm{G}$ 比の低下 が認められたが，その他に異常はなかった（表 1 ）。

処置および経過：昭和 58 年 11 月】, 生検のため に，局所麻酔下にて，前方部（ 167 部口蓋側）クルミ大 尰瘤の全摘出術を施行した，摘出物の病理診断は線維性 エプーリスであった。昭和58年12月—より昭和59年 1 月【にわたり，保存不可能な $\underline{32}|，| \underline{3-8}, \overline{8543} \mid$,

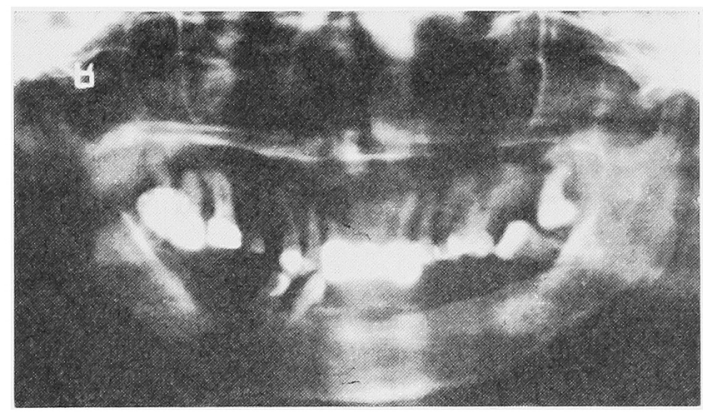

写真 2 初診時のオルソパントモグラム

|学拔去した， 6 拔崡の際，歯槽突起の吸収と上顎洞 への交通が認められた. 残存雪のスケーリング，ブラッ シング指導を゙行い, 口腔内清掃に努めた後，白部の閉 鎖を確認でさた，さらに，昭和59年 2 月】, 局所麻酔

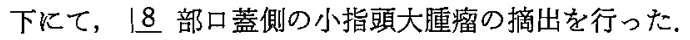
腫瘤は有茥性であった。基底部より骨膜を含めて切除を 行い, 基底部骨膜下の健康骨を確認し，切除部の縫合を 行い終了した．術後の経過は良好であった（写真 4).

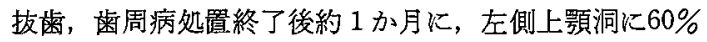
ウログラフィン $15 \mathrm{~m} l$ を注入し，上顎洞の機能検查を 行った（写真 5，6）. 洞内の造影剂は排泄されており, 上㴿洞の排泄機能は，正常であった。また，昭和61年 1 月—, 術後約 2 年の前額断断層写真で, 洞粘膜の肥厚 


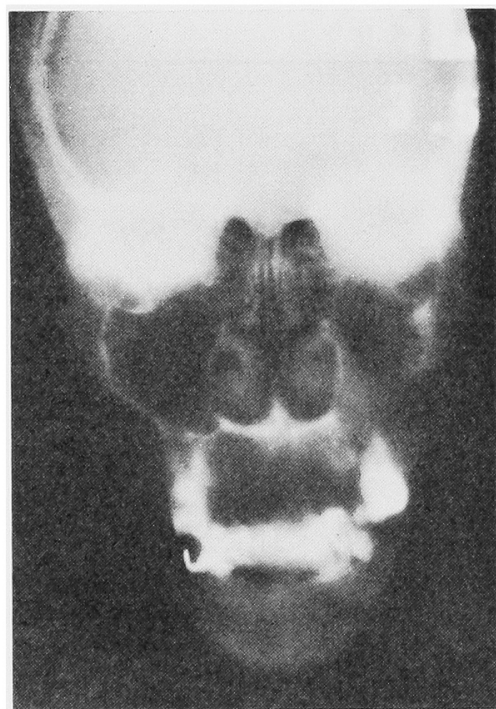

写真 3 前額断断層写真

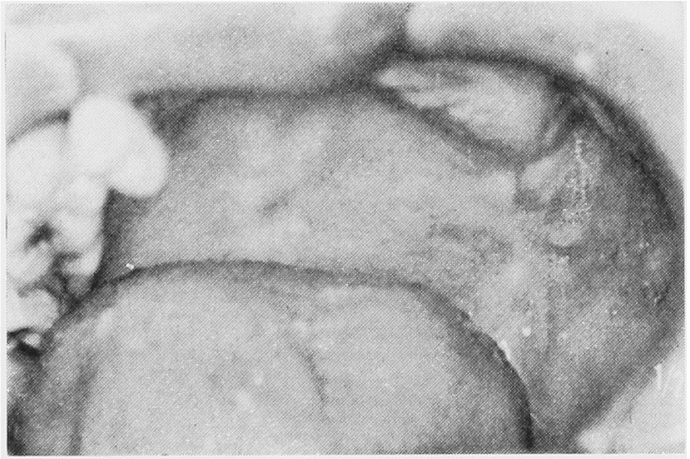

写真 4 腫瘤摘出後の口腔内写真

の消退が認められた（写真 7)。

\section{摘出物所見}

肉眼的所見： 67 部の尰瘤は， $3 \times 2.5 \mathrm{~cm}$ (写真 8 ), 18部の腫瘤怆， $1.5 \times 1.3 \mathrm{~cm}$ (写真 9) で, ともに有茎 性で表面はすべて粘膜で括拈われ，平滑で多面体を呈し ていた。

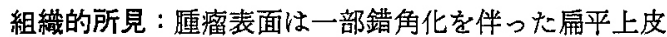
で抢扔われて扣り，上皮下は線維性組織で，不規則汇錯 走する膠原線維が認められた（写真10，11）.

\section{考察}

エプーリスとは，歯肉部に生じた良性の限局性腫瘤を

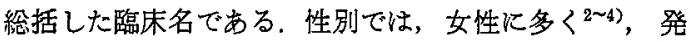
生部位については，上買に多く発生していると報告され ている。季たエエプーリスは，自覚症状なく，症状を自

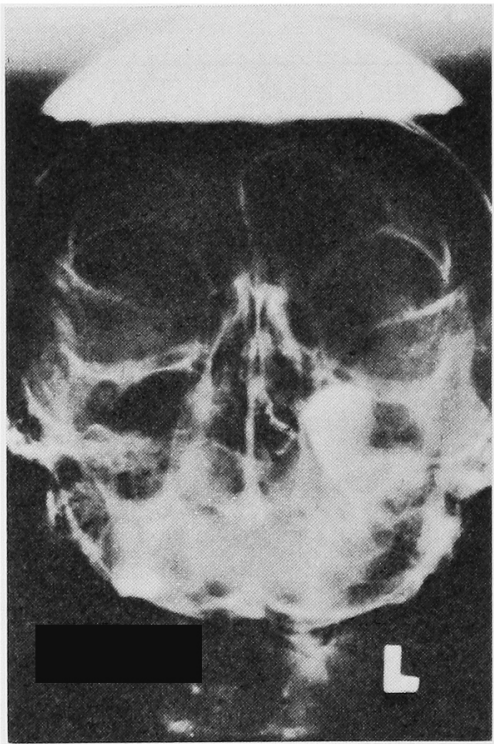

写真 5 60\%ウログラフィン注大直後

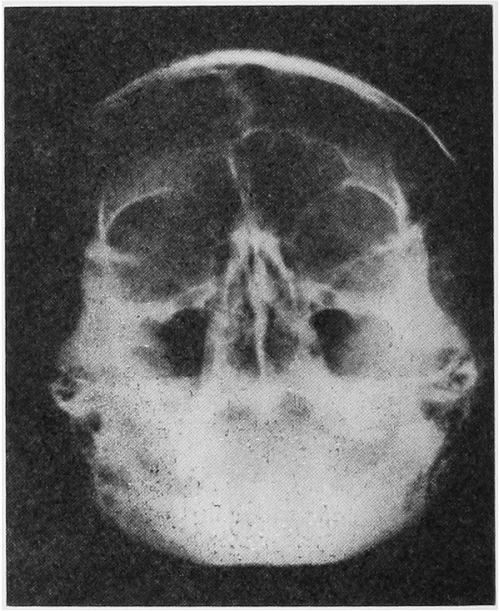

写真 6 60\%ウログラフィン注入 1 週間後

覚してから来院までの期間は比較的長く，1年以内が多 いといわれている゙.

本症の発生原因は不明とされているが，全身的因子と 局所的因子が考えられている，全身的因子としては，女 性ホルモンがあり, 妊娠 $2 \sim 3$ か月の初期に発生し, 出 産後に縮小，消失するとされる娃娠性エプーリス，思春 期汇発生する思春期性エプーリスなどがある，局所的因

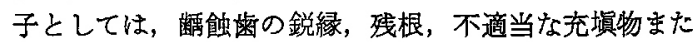
は補綴物，歯列不正，楊子の使用，多量の歯石沈着，菌 周疾患などの慢性刺激をあげている4, 。本症例の場合， 残存歯すべてにわたり高度の歯周疾患功認められ，歯肉 の発赤, 腫脤，歯の動摇があり，歯石の沈着も著明であ 


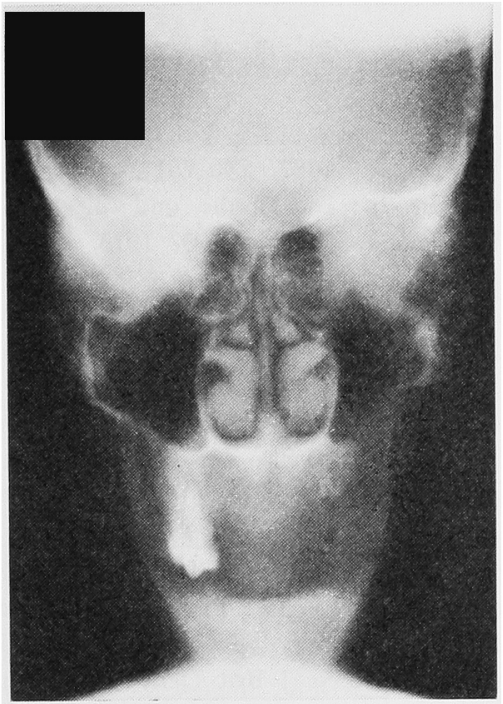

写真 7 初診 2 年後の前額断断層写真

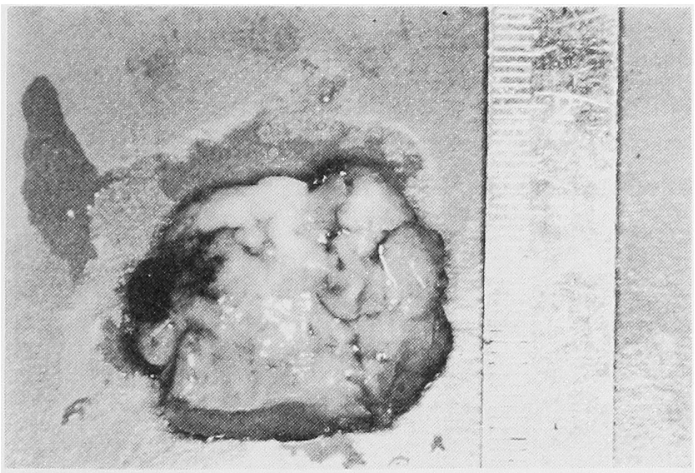

写真 8 前方部腫瘤の摘出物

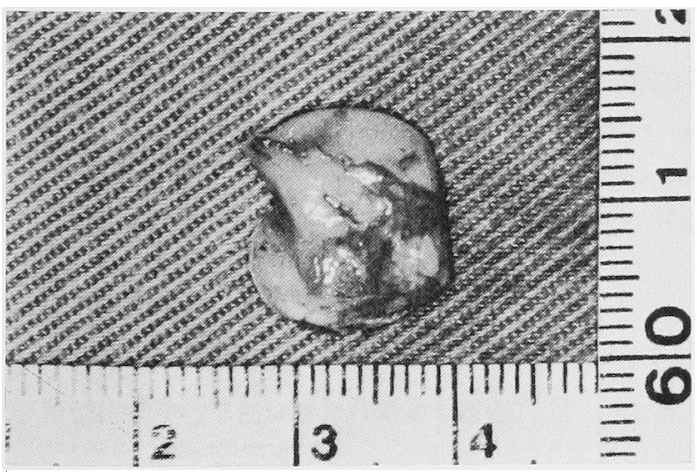

写真 9 後方部缠瘤の摘出物

ったことよりこれらの慢性刺激が促進因子となり，エ プーリスが発生したと考えられる。

病理組織的分類は, 肉芽腫性, 線維性, 血管腫性, 線

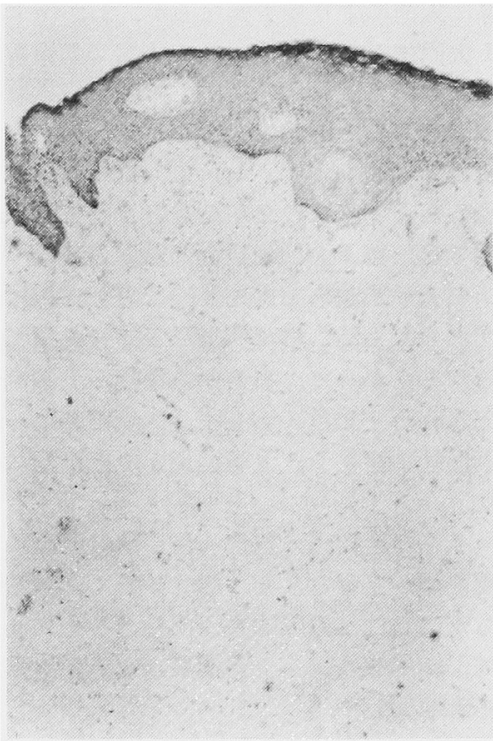

写真 10 摘出物の彁桩大組織像

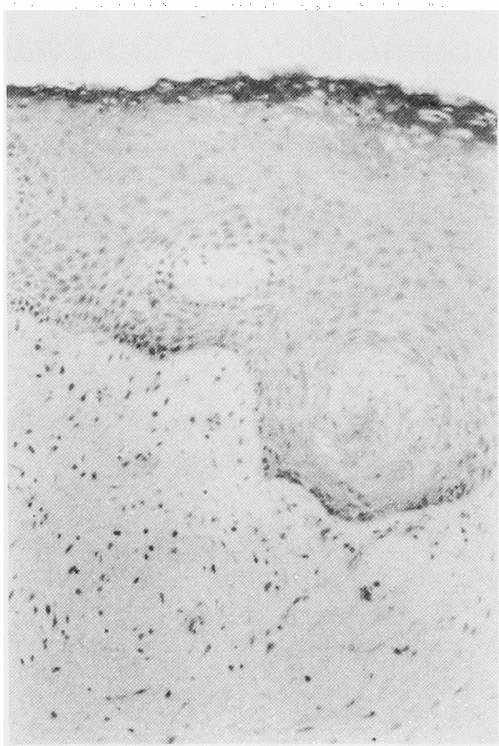

写真 11 摘出物の強拡大組織像

維腫性，骨形成性および巨細胞性に分類されている4). 今回，われわれの経験したエプーリスでは，腫瘤表面が 一部錯角化を伴った扁平上皮で拉おわれていた，上皮下 は線維性組織であり，不規則に錯走する膠原線維が認め られた。病理診断は, 線維性エプーリスであった。

さらに，本症例に执いては，初診時の前額断断層写真 に，左側上䫇洞粘膜の肥厚があり，上頡洞炎の存在が認

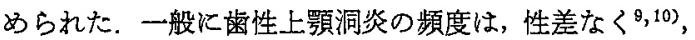
年齢では20歳代に多い゚ 11) と報告されている，原因歯に 
ついては，人種により多少異なるが，わが国において は，第 1 大臼歯が最も多く，次いで第 2 大田歯，第 3 大 臼歯であると報告されている12，原因歯の状態について は，齢蝕である場合が多く，また，無噵歯が大部分を占 めると報告されている ${ }^{13)}$ 。 しかし，盲整から资症が上額 洞へ波及した症例も少数ながら報告されている ${ }^{9,13,14)}$.

本症例では，第 1 大曰歯抜歯の際，直径約 $0.5 \mathrm{~cm}$ の 上顎洞への交通が認められたが，この骨欠損は，本歯が 有髄歯であったため，根尖病巣による骨欠損ではないと 思われる、したがって, 盲哇から炎症が上顎洞へ波及し たと考えられる。 また，エプーリス摘出時に，基底部下 には健康な骨が存在し，上罰洞炎との直接的関俰は疑兄 なかった。

エプーリスの全摘出，拔歯，歯周病処置後に左側上顎 洞の粘膜機能が正常となり, 約 2 年後には洞粘膜の肥厚 が消退したことは，原因除去されたと考えられる。

よって, エプーリス，上顎洞炎ともに歯周疾患が原因 と考えられた。

\section{結語}

1.われわれは，巨大なェプーリスおよび上㴿洞炎の 併発例を経験した。それらはともに辺縁性歯周組織炎が 誘因と考光られた。

2. エプーリスの全摘出，抜歯，歯周病処置により， 上狉洞粘膜の肥厚が消退した。

稿を終えるにあたり，こ想切なるご教示を睗りました 大阪菌科大学第 2 口腔外科学講座岡野博郎教授に深甚の 謝意を表します。

本諭文の要旨は, 第29回日本口腔外科学会総会（昭和 59年 9 月，北海道）に拈いて発表した。

\section{引 用 文 献}

1）石川梧朗，秋吉正豊監修：口腔病理学 II。永末 書店, 京都, 1982, 740-751頁.

2) Gruner, E.: Die Epulis und ihre Therapie. Dent Monat Z 33: 63-87 1915.

3) 張 丕明：本学における最近 6 年間のエプーリ ス患者の臨床統計的䚁察。宩学 58:212-221 1970.

4) 石川梧朗, 秋吉正豊監修: 口腔病理学 II. 永末 書店, 京都 1982, 229-240頁.

5）岩崎弘治，暒川幸良，他：エプーリス63症例の 臨床的観察。日口外誌 20：332-337 1976.

6）好士和夫：エプーリス（㫧肉腫）の臨床的なら びに組織学的研究. 口病誌 $26: 1666-16821959$.

7) Cook, B.E.D.: The fibrous epulis and the fibro epithelial polyp: their histogensis and natural history. J Brit Dent Assoc 12 : 3053091952.

8) Blum, T.: Pregnaney tumors: astudy of sixteen cases. JADA 18: 393-410 1931.

9）堀口申作，三浦眞一：歯性上顎洞炎の臨床的研 究 (総括的钼察). 耳展 $26: 459-4641954$.

10）毛利 学, 西尾正寿, 他: 蒾性上顎洞炎の臨床

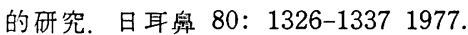

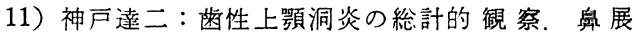
46 : 786-788 1953.

12）上條雍彦：上顎洞の位置と炎症（上顎洞炎）の 関係. 口腔解剖学 1 骨学. アナトーム社, 東 京, 1966, 207-216頁.

13）若林一块，渡辺慎也，他：柬性上顎洞炎の臨床 的研究. 城鄫大紀要 11：388-397 1982.

14）森本正紀，和田宗一：檤性上顎洞炎に於ける原 因菌の病態並に其處置に就て.耳鬼臨 $37: 378-$ 3841942. 